\title{
The Delineation of Passion in Sir Philip Sidney's Astrophil and Stella
}

\author{
Sarkawt Amir Sabir \\ Department of English, Koya University, Koya, Iraq
}

Email address:

sarkawt.sabir@koyauniversity.org

To cite this article:

Sarkawt Amir Sabir. The Delineation of Passion in Sir Philip Sidney's Astrophil and Stella. International Journal of Literature and Arts. Vol. 3, No. 4, 2015, pp. 54-59. doi: 10.11648/j.ijla.20150304.14

\begin{abstract}
The research tries to approach Philip Sidney (1554-1586) as a model of passionate poet and lover. Through the extensive influence of Greeks' and Petrarch's love sonnet cycles, Sidney wrote his sonnets about the abject knightly lover, to suit his prime purpose of delineating the uncontrollable passion, who is condemned by the coldness of his beloved. It also examines the delineation of passion in Sidney's sonnets cycle, namely Astrophil and Stella, in which selected sonnets as well as songs revolve around the uncontrollable passion of a sorrowful and burning lover, who falls in love, and experiences the agony of rejections and the effects of betrayal by his beloved. It often expresses Astrophil's pain and frustration at Stella's diffidence. Sidney carries these passionate topics beyond their predictable limitations, using them simply to begin a discourse. For that matter, through the convention and the influence of Petrarch, Sidney portrayed passion in his sonnets and his songs, breathing into it, a lyrical melody, a meditative energy and an aesthetic interest, transforming the entire sonnet cycle into a personal direct statement.
\end{abstract}

Keywords: English, Literature, Poetry, Passion, Sidney

\section{Introduction}

Sir Philip Sidney (1554-1586) is considered one of the foremost Renaissance writers of his time. Despite the fact that the Elizabethan Age (1533-1603) produced Shakespeare, Spenser, Johnson, Marlowe and many others, Sidney seemed to stand apart quite conspicuously. He is Jack of all trades and a master of all of them. He was a traveler, a courtier, a statesman, a knight, a poet and a soldier. These shimmering words as well recall an incident that made the world esteem Sidney as how fine and courtier he was. He took part in a skirmish, known as the battle of Zutphen in 1586. In it, he was struck in the last charge in his thigh by a musket ball, a wound that he would have escaped had he not thrown away his thigh pieces on seeing that lord marshal was not wearing his. Additionally, as he was putting the bottle to his lips, he noticed a dying soldier. [1] He delivered it to the poor man, saying these words: "They necessity is yet greater than mine." [2] The best way to portray more of his noble characteristics without reservation is through Ophelia's words in Shakespeare's Hamlet when she says:

Oh, what a noble mind

The courtier's, soldier's, scholar's, eye, tongue, sword,
Th' expectancy and rose of the fair state,

The glass of fashion and the mould of form,

Th' observed of all observers [3]

In his short life, Sidney wrote three major works on which his popularity rests both as a literary theorist and a poet. These works were Arcadia (1580), Apology for Poetry (1595) and Astrophil and Stella (1591).

\section{Astrophil and Stella (1591)}

Philip Sidney wrote Astrophil and Stella1 in 1582 when he was staying in Wales with his father, to celebrate an affair he had with a girl named, "Penelope, the wayward daughter of Walter Devereux, first earl of Essex, and sister of Robert

\footnotetext{
${ }^{1}$ According to The Oxford University Press collection of Sidney's major works has this to say about the title: there is no evidence that the title is authorial. It derives from the first printed text, the unauthorized quarto edition published by Thomas Newman (1591). Newman may also have been responsible for the consistent practice in early printings of calling the lover persona 'Astrophel'. Ringler emended to 'Astrophil' on the grounds of etymological correctness, since the name is presumably based on Greek aster philein, and means 'lover of a star' (with stella meaning 'star'); the 'phil' element alluding also, no doubt, to Sidney's Christian name.
} 
Devereux, second earl of Essex, queen Elizabeth's favorite." [4] Some years before Penelope's arrival at court in 1581 and her marriage to Lord Rich in the same year, there had been some thought of a match between her and Sidney, which came to nothing. Eventually, she became the mother of a large family of children. The greater number of Sidney's sonnets were, doubtless, addressed to her after she had become lady Rich. Sidney did not intend his sonnet sequence to be published. However, it circulated in manuscript, and then it was published posthumously in 1591. [5]

Astrophil and Stella is a sonnet cycle of 108 sonnets and 11 songs whose prime focus is on Stella, Astrophil's beloved, with rhyme scheme of abba-cddc-efef-gg. The word sonnet is an Italian word for a 'little sound' which was created by Francesco Petrarch (1304-1374), an Italian scholar and a poet. The sonnet comprises fourteen lines, and each line contains 10 syllables and arranged according to a fixed pattern. It is usually accompanied by musical instruments. The names of Astrophil and Stella are derived from Greek and Latin words. Astrophil is a Greek word for 'star lover' and Stella is a Latin word for 'star.' His choice of star lover and star shows the direct pointer to the passionate distance Astrophil feels for Stella. Because the names have been derived from the Greek language, it becomes possible to believe that Sidney displays clear references to Homer's Penelope in his Greek epic poetry, The Odyssey. Sidney also designed his sonnets to be made of only 108 sonnets simply to demonstrate the 108 suitors of Penelope, who played a game of striving to determine who could court her. [6]

The sonnet cycle starts with Astrophil falling madly in love with a beautiful woman named Stella. Although she does not show him any particular favor in the first thirty sonnets, Stella tries to be kind to him. Ultimately, she marries another man, a fact that Astrophil discovers in the middle of the sonnet cycle. Because she is extremely unhappy in her marriage, she eventually begins to return Astrophil's affection. She first begins to express affection for him around the sixtieth sonnet. It is at this point in the plot that their love affair finally begins to move forward. Astrophil no longer describes Stella's beauty, but he describes real interactions that occur between the two. However, as soon as Stella admits her love for Astrophil, the affair becomes far more problematic. [7]

The first major conflict that immediately appears in their relationship is Astrophil's well-built passion for Stella. Because of her marriage vows, she is unwilling to enter into a physical relationship with Astrophil. She offers him her love on the condition that their relationship will be platonic. Astrophil is satisfied with this arrangement for a few sonnets, but then his physical and substantial passion for Stella begins to overwhelm him. Several sonnets are devoted to this conflict: his rational mind recognizes that the only way to please Stella and continue the affair is to suppress his physical desire for her. Yet, Astrophil's uncontrolled passion replaces his rationality. In Song 2, Astrophil kisses Stella while she is sleeping; an act which is the closest Astrophil ever gets to a physical consummation of his passion. Stella realizes that even though she loves Astrophil, the affair cannot continue if he needs his passion to be consummated. As a result, Stella ends the relationship. [8]

The relationship becomes more dramatic and complicated as the sequence continues. Stella falls ill in Sonnet 101, which spurs Astrophil to confess his love for her again. He serenades her under her window in Song 11, hoping that she will change her mind and stay with him. Yet, Stella refuses to sacrifice her husband and her reputation. For that matter, she dismisses him forever. Astrophil ends the sonnet alone and isolated, albeit he retains some happiness in the knowledge that he loved Stella and that she once loved him in return. [9]

\section{The Delineation of Passion in the English Renaissance}

With the dawn of the English Renaissance, England began to feel the full impact of the Italian Renaissance, which furthered the way towards an early modern era. This transition brought about the breakdown of feudalism, the rise of nationalism, the secularization of education, and the revival of the classics. The latter was vital simply because the humanist scholars one of whom Desiderius Erasmus (1466-1536) began to translate the Greek texts into Latin and the vernacular, which later on became known to England as humanism. [10]

Passion during the English Renaissance was a major focus due to varied influences that affected writers in general and poets in particular. First, it was the newly-translated Greek stories of passion that gave food for thought to the English writers to focus on the development of the erotic passion between a man who falls passionately in love with a married woman. This idea was inspired even more when the English writers delved into reading and studying the Socratic and Aristotelian attitudes to human nature with respective views of reason, the passions, grace, virtue, and akrasia, which means, the weakness of will. These views attracted many Renaissance writers to include them in their writings. They became more interested in the ones that concerned with the usual conflict between reason and passion. [11]

The dialectical background for the conflict between reason and passion was more than familiar to Sidney's age. Briefly, it derives from the concept of the soul as composed of rational and irrational or passionate principles, a concept shared by both Plato and Aristotle. For instance, according to Aristotle, these two principles are in harmony only when the rational can govern the irrational:

For we praise the rational principle of the continent man and of the incontinent, and the part of their soul that has such a principle, since it urges them aright and toward the best objects; but there is found in them also another element naturally opposed to the rational principle, which fights against and resists that principle ... or shares in it, in so far as it listens to it and obeys it. [12]

These two principles are naturally hostile leads to the notion that reason is the instrument of self-control when the passions are stirred. What unites these classical positions is their common emphasis on the role of reason in ruling the mind. 
Reason is extremely vital because it "intuits transcendental values, grasping a divinely sanctioned, eternally present morality," [13] which is the bond of all society. In contrast, passions are viewed by most Greek philosophers as "wholly disruptive to this order and hence as forces ought to be suppressed or eradicated." [14] Accordingly, Sir Philip Sidney portrays the idea that when a man as in Astrophil falls passionately in love with a girl as in Stella who dooms to be with another, such forces as passions will disrupt the norms of his functional social relationship.

Second, another popular form that influenced the English Renaissance writers in focusing on the use of passion in their works was the influence of the medieval chivalric romance and the courtly love. This genre of romance drew heavily on fine amors which is the courtly love tradition as famously set down in Andreas Capellanus's De Arte Honeste Amandi in thirteenth century. As C. S. Lewis argues, passion in the romance of the Middle Ages expressed itself largely through adultery. Unlike the symmetrical attraction that occurs between the hero and heroine of Greek romance, the lovers in medieval romance were represented as uneven whether on account of an adulterous liaison or unrequited love. [15] It is the effect of passion that drives the courtly lover voluntarily into humbling himself before his lady to the extent that he obeys her every command. This still current notion originates in the works of critics like C.S. Lewis, who described the experience of courtly love as:

The Lover is always abject. Obedience to his lady's lightest wish, however whimsical, and silent acquiescence in her rebukes, however unjust, are the only virtues he dares to claim. There is a service of love closely modeled on the service, which a feudal vassal owes to his lord. The lover is the lady's "man." [16]

The renewal both of chivalry and of courtly love in the Renaissance are obviously connected and governed by codes of aristocratic behavior and perception. As the Renaissance proceeded, especially under Queen Elizabeth, politics and patronage converged with love and passion. Both became almost interchangeable because of:

The convergence of two aspects of passion: passion for reward and passion for the unattainable ideal that gives life meaning. The first one portrays men courting patrons and mistresses because they want some material return, financial or sexual or both. Their prime purpose is to satisfy their lusts, to seek position, power, and social aggrandizement. The second one is men following feudal or worshiping ladies because they thus give meaning to their lives and confirm their worth, gain honor, prove their nobility and establish their own inmost identity as persons. [17]

That kind of passion simply brought to the early Christian world a heterosexual paradigm of amatory relations. However, the new erotics carried with it an ethic of chastity. The lovers remain true despite the fact that both suffer ordeals of separation and loyalty. Accordingly, the passion between the young man and woman ought to be fulfilled in matrimony, and this marital union is based on the necessary factor of parental consent. [18] Therefore, the Renaissance period turned to the
Greeks in nearly every field, predominantly in theatre, philosophy and literature. Even in their poetry, the Renaissance poets included much of the Greek mythology, conjuring up images of Venus and Cupid when speaking of matters of the heart and passion.

\section{The Delineation of Passion in Sidney's Astrophil and Stella}

Sir Philip Sidney presents the delineation of passion as a major theme in his sonnet cycle Astrophil and Stella. He presents the persona, Astrophil, who finds himself in a battleground upon which his passions become his enemies because they are ineradicable and uncontrollable. [19] The delineation of passion becomes a subversive element in the sequence because not only is it an attempt against the literary conventions of the Platonic expression of love, but also it is a rebellious attitude towards the strict moral and religious canons of Elizabethan England. He begins his sonnet by having a pure love that progressively degenerates into an obvious expression of his sexual desires due to an increase of his passion. He begins to experience the uncontrolled growth of passion, being sent loose at large:

Loving in truth, and faine in verse my love to show,

That she (deare she) might take some pleasure of my paine:

Pleasure might cause her reade, reading might make her know,

Knowledge might pittie winne, and pity grace obtaine,

I sought fit wordes to paint the blackest face of woe;

Studying inuentions fine, her wits to entertaine, [20]

The first sonnet introduces the theme of love whose force is passion "to show," (1) that it has an enchanting power over Astrophil's mind. He demonstrates that his love is sincere and he writes these sonnets on purpose so that his beloved may read them. Thus, after realizing how intense the force of his passion for her is, she will pity him and that soon will make her love him. He intends to create pity out of his passion to display his sadness. Even though he tries to imitate others, that's, the ancients, in expressing his passion, they are quite inadequate to express the intensive passion he feels for his beloved. For that, he remains "helpless" (12) to the point that he feels he was "Biting my trewand pen, beating myselfe for spite," (13). He has struggled to express the pain and the misery of his passions, and for that he tries to look at the works of others to procure inspiration. However, his Muse, whose figure is Stella imprinted in his heart, steps in to advise him by saying, "Fool... looke in thy heart, and write" (16) to find a solution to his incessant agony and that is he must look into his heart to write. [21] The heart may be the seat of passions, but what Astrophil finds in his heart is the image of Stella. The representation of the male suffering by passion is an effective method to touch women's feelings and make them subdue to their requests. It is through this method that Astrophil his passion can be pitiable by all who will look at him.

Sidney, in the following sonnet, presents passion as a passive participant in the progression of love. Astrophil 
clearly has no control over his emotions. His passionate conflict augment as his "Love gave the wound, which, while I breathe, will bleede;" (II: 2), he becomes aware of the power of his passions despite knowing that he was raised as a protestant and ultimately he needs to restrain them at all costs. If he does not, his passion will "bring[s] people together only to plunge them into a self-shattering and solipsistic that derives them apart." [22]

Hence, passion is a destructive tool. He knows for sure that no matter how much he craves for Stella, it is already a lost battle. This is where the endless laments emerge through the use of metaphor, simile and personification when he feels that he has "even that footstep of lost libertie / Is gone;" (9-10) and has become "like slave-borne"(10).

$\mathrm{He}$ is a slave to passion.

I call it praise to suffer Tyrannie;

And now employ the remnant of my wit,

To make me selfe believe, that all is well,

While with a feeling skill I paint my hell. (13-14)

Because of the slow and steady progression of his passion, he is unable to guard himself. He has no whatsoever power to evade it. Once the passions infiltrate, then they go viral. Indeed, Astrophil does descend into his own ego, and in the second sonnet he reveals that he is constructing poems about his passions to keep stimulating more passion as well as, paradoxically, to maintain the integrity of his wit. Astrophil is, as he says, painting his hell and additionally the ruin of his wit. His self-focus is directing him toward a disastrous failure as it renders him unable to control his passion. [23] Thomas Roche observes that Sidney wants us:

To be instructed by the image of a man whose reason gives way to his will and whose hopeful desires finally lead him to despair. Astrophil is not a hero, and he is not a hero precisely because he succumbs wholeheartedly to the pursuit of his desires. He teaches morality by negative example... Sidney is using Astrophil's journey from hope to despair as a fictional device for the analysis of human desire in Christian terms. [24]

In Sonnet 4, Astrophil addresses "Virtue" but acknowledges that it has set a "[de]bate betweene [his] will and wit" (2) over whether or not Stella is worthy of his passion. He argues that this fundamental Petrarchan moral question is beside the point, for if "Virtue" were to see the image of Stella in his heart, "Virtue" would love her also. His passion becomes a kind of obsession that takes over his entire body to the extent that he not only rejects 'Virtue' in Sonnet 4, but also convinces that the image of Stella in Astrophil's heart will be sufficient to make 'Virtue' himself fall in love with her [25]:

I sweare, my heart such one shall show to thee,

That shrines in flesh so true a deitie,

That, Virtue, thou thyself shalt be in love. (12-14)

In the same way of pursuing his sensual passion, he finds the reality of his passion for Stella is incompatible with "Morality" in Sonnet 5. Here, Astrophil lists a series of truths, one of which is that people were born "to serve, / The inward light," (5: 1-2). The inward light stands for human mind, and the other truth is what he calls that of "Cupids dart / An image is, which for ourselues we carve," (5-6) to become "foolse." He continues with another truth:

True, that on earth we are but pilgrims made,

And should in soule up to our countrey move:

True, and yet true that I must Stella love. (5: 8-14)

The other truth is that people are only pilgrims on this earth which should concentrate on their souls rather than their passions. Even though he recognizes the truth in all statements he made, he is unable to separate his rational understanding of the passion in his heart. Stella has become an idol, an image taken into Astrophil's heart in place of God. Astrophil suggests that the Church and clergy are neglected by most people like him, though they may be, because Christian theology subordinates human love to divine love. All of the forces he establishes in this sonnet with the idea of truth in all of them, he concludes that his passion steers clear of all of them and eventually loves Stella. His passion for her is the truth. Astrophil affects a more penitential tone, but he is still arguing the same case in favor of pursuing passion and indulging the ego. [26]

Reason, like Virtue, is assaulted in Sonnet 10 as Sidney calls for it to "leave love to will" (8) in an argument that polarizes thought and passion or "sence" (2) as well as the higher and lower desires of wit and will. If Reason must offer resistance to sensual passion, Astrophil argues that it will need passion and love as a motivation, so it too will inevitably succumb to "Stellas rayes" (12). He is quite able to see his impending loss of self, ironically induced by rejecting everything but his own passion, but he unswervingly insists that he is unable to escape his doom and continues to write: [27]

I see my course to loose my self doth bend:

I see and yet no greater sorow take,

Then that I loose no more for Stellas sake. (18: 12-14)

These rejections progressively decrease the range of Astrophil's wit and increases the effect of his passions. In Sonnet 25, Astrophil upholds and attempts to justify his passion for Stella by positing the reality of his experience from Plato's idealism and the Neoplatonic scale of love:

The wisest scholler of the wight most wise,

By Phoebus doome, with sugred sentence sayes,

That Vertue if it once met with our eyes,

Strange flames of Love it in our soules would raise.

But for that man with paine this truth descries, (1-5)

In the Phaedrus, Plato, the wisest pupil of Socrates, declares that if an individual sees Virtue in a physical form, that individual will immediately fall in love with it. Astrophil acknowledges the truth of this declaration by seeing such Virtue in Stella's form that he himself falls in love with her. Implicitly, Plato is incapable of addressing the reality of the pains of passion that Astrophil feels. [28] In Sonnet 32, the shade of Stella is approached by Astrophil as a dream from Morpheus in the underworld of sleep, "Morpheus the lively sonne of deadly sleepe, / Witnesse of life to them that living die:" (1-2) He is the son of the god of sleep. Astrophil has a close relationship with him. Even while he is asleep, Astrophil asserts that his passions are active and open, which allows him 
to accept the dream image of Stella as a reality. He resorts to him with a question. He asks him how he can create such a brilliant trait of Stella in his head. While he is asleep, he finds a world where everything is accessible for free such as "ivory," "rubies," "pearls" and "gold" to portray them as metaphors for Stella's "skin," "lips," and "head." He responds:

Foole! answers he;

no Indes such treasures hold;

But from thy heart, while my sire charmeth thee,

Sweet Stellas image I do steal to mee. (12-14)

While his passions momentarily assuaged, Astrophil soon finds greater problems when the focus turns to the dream-image itself. He will not sleep well again. In Sonnet 38, Stella's image is beyond his power to control, and the passion is the prime cause of it. Every time he tries to call Sleep again to regain Stella's image, he fails. Stella has "had slain" (14) Sleep with her beauty. [29] In sonnet 50, Astrophil struggles with the power of passions over him. He is unable to keep them inside. His passions form endless thoughts of her, forming the sonnet sequence:

Stella, the fullnesse of my thoughts of thee

Cannot be staid within my panting breast,

But they do swell and struggle forth of me, (1-3)

His passion for her is so great that he cannot even destroy the inadequate poems he has written, "And now my pen these lines had dashed quite," (12) simply because "their forefront bare sweet Stellas name.” (14) In sonnet 62, Astrophil is filled with violent passion:

Late tyr'd with wo, even ready for to pine

With rage of love, I cald my Love unkind;

She in whose eyes love, though unfelt, doth shine,

Sweet said, that I true love in her should find. (1-4)

Astrophil calls Stella ruthless because she refuses his advances, declaring that he should look for virtuous love. Also, she delineates that the only love she accepts is that from a "nobler course, fit for my birth and mind" (8) to fit her birth and social station. She refers to his passions as "tempests" because they are a metaphor for violence. Both are uncontrollable. With all that, he cannot get rid of his passionate love, so he comes up with a declaration that he would rather she did not love him, "love me not," (14) if virtuous love is the only kind she offers. This, however, does not work when Astrophil realizes that his passion will not be so easily managed: "But ah, Desire still cries, give me some food" (72: 14). Astrophil's plea for some "food" for his passion is a clear denial of the Petrarchan, Neoplatonic ascension of the soul through love, and so is his implicit refusal to banish passion from himself as Stella has "banisht" (14) it from her. [30] In Sonnet 108, Astrophil is frustratingly sad:

Leave, me, O love which reachest but to dust,

And thou, my mind, aspire to higher things.

Grow rich in that which never taketh rust; (1-3)

Despair takes hold of Astrophel's delight and destroys it.

He returns to the darkness of his existence without Stella's sun, thinking only of the irony that he still must take joy in the thought of her. These sonnets are followed by 11 songs. Each of the eleven songs has an important role in perpetuating the delineation of passion in the sonnet sequence. Of all the songs, Song 2, Song 8, and Song 11 are particularly important in terms of delineating passion. For instance, the stolen kiss in Song 2 is the closest Astrophil ever gets to the manifestation of his physical passion for Stella. The kiss itself inspires several sonnets as Astrophil replays the moment in his imagination. Song 8 is the beginning of the end in their relationship; Stella admits that she loves Astrophil, but she is too concerned with her honor and reputation to leave her husband for him. In song 2, Astrophil steals a kiss from Stella while she is sleeping: [31]

Oh, sweet kisse! but ah, shes waking!

Lowring beautie chastens me:

Now will I for feare hence flee;

Foole, more Foole for no more taking. (25-28)

The kiss only increases his frenzied passion for more, a term he repeats often, because, once taken, it becomes yet another abstraction in his poetry. In this manner, Astrophil consistently transfers the objectivity of sense and experience into the subjective domain of his own mind. In Song 8 , he receives the devastating news that Stella has quit loving him and their relationship has been put paid to it once and for all:

Therefore, deare, this no more move,

Least, though I leave not thy love,

Which too deep in me is framed,

I should blush when thou art named.

There with all away she went,

Leaving him to passion rent,

With what she had done and spoken,

That therewith my song is broken. (81-88)

Finally, what Astrophil experiences was an inside and outside passion: the inside passion refers to a genuine passion within the heart, the mind, and the soul while the outside passion refers to the external signs imprinted in the words and in the body. Even the loss of Penelope Devereux detracts nothing from the poetic character of his life, for he never lost her passion and the fine strength of the sonnets. Astrophil and Stella shows what joy that passion was to his life albeit she could never be altogether his.

\section{Acknowledgements}

I am sincerely indebted to Professor Dr. Namiq Othman and Professor Harith I. Turkey for their accurate and useful remarks and the facilities they favorably presented to me, during the writing of this research paper.

\section{References}

[1] Kenneth Muir, "Sir Philip Sidney (1554-1586)" in British Writers: William Langland to the English Bible, vol. I, G. E. Ian Scott- Kilvert, (New York: Charles Scribner's Sons, 1979), pp.160-175. qtd., in ibid.

[2] William Shakespeare, Hamlet (New York: Scott, Foreman and Company, 1980), Act III, Scene 1, lines: 155-157, p. 67. 
[3] Sidney Lee and D. Litt, "The Elizabethan Sonnets: Sir Philip Sidney's Astrophil and Stella" in The Cambridge History of English and American Literature, Vol., III, A. W. Ward and A. R. Trent, eds., (New York: G.P. Putnam's Sons, 1907-21), p. 335.

[4] Elizabeth Porges Watson, Unbridled Passion: Chivalric Metaphor and Practice in Sidney's Astrophil and Stella (Oxford: Oxford University Press), pp. 117-118.

[5] Surjit S. Mehar, Spenser and Sidney: Selected Sonnets and Poems (New Delhi: Rama Brothers India PVT. LTD., 2009), p. 13.

[6] Caitlin Vincent, "Astrophil and Stella Summary" in http://www.gradesaver.com/astrophil-and-stella/study-guide/s hort-summary/ (retrieved 30th January, 2014), p. 1. Ibid, p.2. Ibid.

[7] Cf. "The English Language in the Age of Shakespeare" in The New Pelican Guide to English Literature, Vol. II, ed. Boris Ford, (England: Penguin Books Ltd., 1967), p. 346.

[8] Christopher T. Mouth, Passions Triumph over Reason: A History of the Moral Imagination from Spenser to Rochester (New York: Oxford University Press, 2007), p. 15.

[9] Roger Crisp, trans., Aristotle Nicomachean Ethics (Cambridge: Cambridge University Press, 2004), p.21.Mouth, ibid. Ibid.

[10] Darlene Ciraulo, Tales of Erotic Suffering: Romance In Sidney And Shakespeare, M.A., (Georgia: The University of Georgia, 1994), p.1.

[11] C. S. Lewis, The Allegory of Love (Oxford: Oxford University Press, 1936), p. 2.

[12] Anthony Law, The Reinvention of Love: Poetry, Politics and Culture From Sidney to Milton (New York: Cambridge University Press, 1993), p. 22. Ciraulo, ibid.
[13] Robert L. Montgomery, "Reason, Passion and Introspection In "Astrophel and Stella,"” Texas Studies in English, 36 (2003), p. 128.

[14] Alexander B. Grosart, The Complete Poems of Sir Philip Sidney (1877) (Oregon, University of Oregon, 1996). Sonnet, I:6-14. Subsequent references to this edition will appear parenthetically in my text, showing the number of sonnets along with their line numbers. Mehar, pp. 15-19.

[15] Daniel Juan Gil, Before Intimacy: Asocial Sexuality in Early Modern England (Minneapolis: University of Minnesota Press, 2006), p. 9.

[16] Daniel Philip Knauss, Love Refinement: Metaphysical Expression of Desire in Philip Sidney and John Donne, M.A., (North Carolina: North Carolina State University Press, 1998), p. 21.

[17] Thomas Roche and William A. Ringler, Jr., eds., The Poems of Sir Philip Sidney (Oxford: Clarendon Press, 1962), p. 205.Vincent, p.16. Roche and Ringler, pp.195-196.

[18] Donna, "Structure, theme and convention in Sir Philip Sidney's sonnet sequence Astrophil and Stella" in http://www.literature-study-online.com/essays/astrophil and stella.html (Retrieved in 2 February, 2014), p. 2. Vincent, p. 22 .

[19] Sonia Hernandez Santano, "Corrupted Platonism in Astrophil and Stella: The Expression of Desire," Sederi 9 (1998), p.86.

[20] Jacqueline T. Miller, "The Passion Signified: Imitation and the Construction of Emotions in Sidney and Wroth" in http://gracewood0.tripod.com/sidney miller.html (Retrieved 16 November 2013), p. 1.Vincent, p.35. 